\title{
Studies on external genitalia of seven Indian species of the genus Spilarctia Butler (Lepidoptera: Arctiidae: Arctiinae) alongwith the description of a new species
}

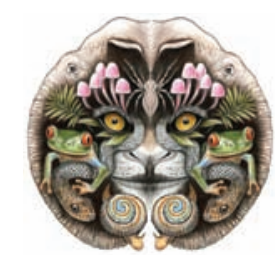

\author{
Jagbir Singh Kirti ${ }^{1}$ \& Navneet Singh Gill ${ }^{2}$ \\ Department of Zoology, Punjabi University, Patiala, Punjab 147002, India \\ Email: 1 prjagbir2005@gmail.com
}

Date of publication (online): 26 June 2010 Date of publication (print): 26 June 2010 ISSN 0974-7907 (online) | 0974-7893 (print)

Editor: Mohammad Hayat

\section{Manuscript details:}

Ms \# 01898

Received 04 December 2007

Final revised received 11 February 2010

Finally accepted 15 March 2010

Citation: Kirti, J.S. \& N.S. Gill (2010). Studies on external genitalia of seven Indian species of the genus Spilarctia Butler (Lepidoptera: Arctiidae: Arctiinae) alongwith the description of a new species. Journal of Threatened Taxa 2(6): 948-960.

Copyright: () Jagbir Singh Kirti \& Navneet Singh Gill 2010. Creative Commons Attribution 3.0 Unported License. JoTT allows unrestricted use of this article in any medium for non-profit purposes, reproduction and distribution by providing adequate credit to the authors and the source of publication.

Author Details, Author Contribution: See end of this article

Acknowledgements: The authors are very grateful to Dr. Martin Honey, Natural History Museum (NHM) London, who rendered his help for the comparison of arctiid collections with the holotypes lying there. Authors are also thankful to the Chief Conservators of Forests, DFOs and other staff of forest department of different states lying under Western Ghats for there cooperation during the collection-cum-survey tours. The financial help given by Department of Science \& Technology (DST), New Delhi in a project entitled "Taxonomic revision of Indian Arctiidae (Lepidoptera)" is also duly acknowledged.
Abstract: Seven species i.e. Spilarctia mona (Swinhoe), S. castanea (Hampson), S. bifascia Hampson, S. coorgensis sp. nov., S. obliqua (Walker), S. casigneta (Kollar) and S. todara (Moore) have been taxonomically treated from the Western Ghats of India. The external male and female genitalic structures of these species have been described and illustrated in detail. A key to the studied species is also given.

Keywords: Arctiidae, Arctiinae, Lepidoptera, new species, Spilarctia, Western Ghats

\section{INTRODUCTION}

Genus Spilarctia was established in 1875 by Butler on the type species Phalaena lutea Hufnagel, 1766, from Germany. This genus was synonymised under Spilosoma Stephens, 1828, by Hampson in 1894. However, in 1901, Hampson described the genus Diacrisia Hübner, 1819, in a broader concept and synonymised 31 genera under it which also included both the genera i.e., Spilarctia Butler and Spilosoma Stephens. Seitz (1910) introduced the division of the family Arctiidae into eight subfamilies and transferred the genus Spilarctia Butler under Spilosominae. Later, Daniel (1943) followed this division in spite of the fact that Strand (1919) treated Spilosominae as a synonym of Arctiinae. Arora \& Chaudhary (1982) and Arora (1983) followed the classification given by Seitz (1910). Holloway (1988) used Spilosoma Curtis (=Spilosomoa Stephens) as a valid generic name. Koda (1988) brought out an important publication on the generic classification of subfamily Arctiinae of the Palearctic and Oriental regions based on the male and female genitalia. $\mathrm{He}$ re-characterized the genus Spilosoma Curtis and Spilarctia Butler and provided suitable status to both these genera in this publication. Kirti \& Singh (1994) studied the genitalic structures of four Indian species i.e. Spilarctia multiguttata Walker, S. casignata Kollar, S. obliqua Walker and S. comma Walker.

In the present study a large sample of 43 representatives were collected from different localities of Western Ghats of India. On close examination of morphological characters, seven species were separated. Out of these, six species were identified from the relevant literature and by comparison with the collections preserved in different national museums viz., Indian Agricultural

Abbreviations: $1 A$ - First anal vein; $2 A$ - Second anal vein; AED - Aedeagus; AMP+HRP - Ampulla \& Harpe (fused); ANT.APO - Anterior apophyses; CO - Costa; CRN - Cornuti; CRP.BU - Corpus Bursae; $\mathrm{CU}$ - Cucullus; $\mathrm{CU}_{1}$ - First cubital vein; $\mathrm{CU}_{2}$ - Second cubital vein; DU.BU - Ductus Bursae; DU.EJ - Ductus Ejaculatorius; FEN - Fenestrula; JX Juxta; $M_{1}$ - First median vein; $M_{2}$ - Second median vein; $M_{3}$ - Third median vein; PAP.A - Papilla Analis; PO.APO - Posterior apophyses; $R_{1}$ - First radial vein; $R_{2}$ - Second radial vein; $R_{3}$ - Third radial vein; $R_{4}$ - Fourth radial vein; $R_{5}$ - Fifth radial vein; $R S$ Radial Sector; SA - Saccus; SC - Subcosta; $S C+R_{1}$ - Stalk of $S C+R_{1}$; SIG - Signum; SL - Sacculus; TG - Tegumen; UN - Uncus; VES - Vesica; VIN - Vinculum; VLA - Valvula; VLV - Valva.

Journal of Threatened Taxa I www.threatenedtaxa.org I June 2010 | 2(6): 948-960 
Research Institute (IARI), New Delhi, Forest Research Institute (FRI), Dehradun and Natural History Museum (NHM), London. One species could not be identified from these sources. This species is described here as new to science.

\section{MATERIALS AND METHODS}

The material for the present study i.e., the adult moths of family Arctiidae were collected exclusively from fluorescent lights during night hours from different localities in the Western Ghats of India. The collected moths were killed with ethyl acetate vapors in the killing bottle. The freshly killed specimens were pinned and stretched on adjustable wooden stretching boxes. The pinned specimens were dried for 2-3 days in the improvised drying chambers. The properly dried specimens were then preserved in air tight wooden boxes, containing naphthalene balls as fumigants. To study wing venation permanent slides of fore and hind wings were made. For this, the methodology given by Common (1970) and advocated by Zimmerman (1978) was followed. For the study of external male and female genitalia, the entire abdomen of the preserved moths was removed, as cutting only the last few segments often damages constituent parts of male and female genitalia (Robinson 1976). The detached abdomen was put in 10\% $\mathrm{KOH}$ for 12-14 hr. in order to soften chitin and dissolve muscles and other soft parts. The $\mathrm{KOH}$ treated material was washed in distilled water and residual traces of $\mathrm{KOH}$ were later removed by putting it in $1 \%$ glacial acetic acid. The abdomen was dissected in $50 \%$ alcohol for taking out the genitalia and adhering unwanted material was cleared in the subsequent grades. After proper dehydration, the material was cleared in clove oil and preserved in a ratio of 3:1 alcohol and glycerol. The diagrams were drawn with the help of a graph eye piece fitted in a zoom binocular.

\section{GENUS SPILARCTIA BUTLER}

Butler,1875, Cistula Entomolgica, 2: 39.

Type species: Phalaena lutea Hufnagel, 1766 , Germany: Berlin; type deposited in Natural History Museum (NHM), London, subsequent designation by Kirby 1877 in Rye Zoo. Rec. $12: 431$.

Distribution: India; China; Korea; Japan; Nepal; Bhutan; Cambodia and Malaysia.

Diagnosis: Labial palpi porrect or porrectly rosteriform. Antennae bipectinate in males, ciliated in females. Forewing with vein $R_{1}$ arising from cell; $R_{2}, R_{3}$, $\mathrm{R}_{4}$ and $\mathrm{R}_{5}$ from a common stalk; $\mathrm{M}_{1}$ from upper angle; $M_{2}$ from or slightly beyond lower angle of cell. Hindwing with vein $\mathrm{Sc}+\mathrm{R}_{1}$ originating towards base of cell; $\mathrm{Rs}$ and $M_{1}$ from upper angle; $M_{2}$ from lower angle or towards middle of discocellulars. Hind tibia with two pairs of spurs. Male genitalia with uncus moderately long, broad at base and gradually narrowing towards tip; acrotergite well developed; fenestrula absent; saccus present; valvae simple with costa narrow and linear, sometimes produced at proximal end; sacculus present, valvula and cucullus not clearly differentiated; juxta trapejoid; aedeagus moderately long and broad; vesica membranous with irroration of small spines; ductus ejaculatorius entering subapically. Female genitalia with corpus bursae membranous, signum present or may be absent; ductus seminalis entering ductus bursae.

\section{Spilarctia mona (Swinhoe) comb. nov. (Figure 1)}

Spilosoma mona Swinhoe, 1885, female, type locality Mahabaleshwar, type depository NHM, London and examined by the junior author.

Spilosoma mona (Swinhoe) Hampson, 1894, Fauna Br. Ind. Moths, 2: 5.

Diacrisia mona (Swinhoe) Hampson, 1901, Cat. Lep. Phal., 3: 280.

Female genitalia: Corpus bursae rounded, membranous, three signa present; ductus bursae long and broad, well sclerotized; ductus seminalis entering corpus bursae; anterior apophyses shorter than posterior apophyses; papilla analis fringed with moderately long setae.

Wing expanse (Half): Female $26-30 \mathrm{~mm}$.

Material examined: 1 female, 08.x.2005, Mahabaleshwar, Maharashtra, 1320m; 1 female, 05.x.2005, Matheran, Maharashtra, 690m.

Remarks: Only three female specimens of mona Swinhoe were collected in 1885 by Swinhoe from Bombay and Mahabaleshwar. Till date, no male representative of this species was studied and associated for mona Swinhoe except Kaleka (2005). It seems that this Indian worker has wrongly identified the above said species collected from northeastern India, because, in the female genitalia of mona Swinhoe three signa are present whereas, Kaleka (2005) has mentioned that the signum is missing in this species. Kaleka (2005) not only shifted it under genus Thanatarctia Butler on the basis of external male and female genitalic structures, but also provided wrong information in his publication that the species mona Swinhoe was studied by Koda (1988) under the genus Spilarctia Butler.

In the present study only two female representatives were collected from Mahabaleshwar and Matheran, which clearly point out that geographically the species is very much restricted. The detailed study of morphological and female genitalic structures of species under reference confirms that it is better to place it under the genus Spilarctia Butler rather than under Thanatarctia Butler or Diacria Hübner. Hence, the proper status of mona Swinhoe has been provided in the present work. 

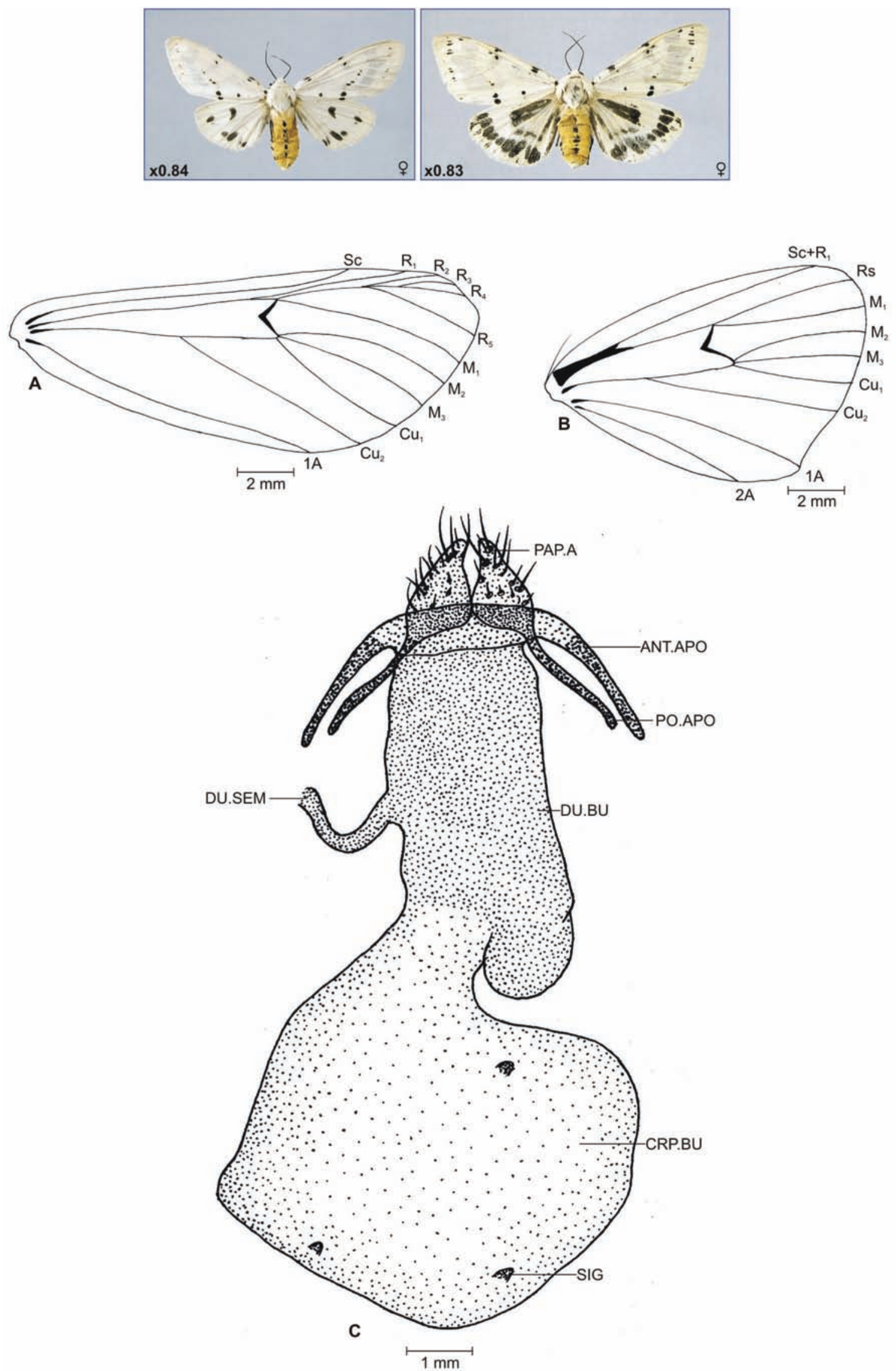

Figure 1. Spilarctia mona (Swinhoe) comb. nov. A - Forewing, B - Hindwing, C - Female genitalia 
Spilarctia castanea (Hampson) comb. nov. (Figure 2)

Spilosoma castanea Hampson, 1893: 9, male, type locality Sri Lanka, type depository NHM, London and examined by the junior author.

Spilosoma castaneum Hampson; Hampson, 1894, Fauna Br. Ind. Moths, 2: 8.

Diacrisia castanea (Hampson) Hampson, 1901, Cat. Lep. Het., 3: 304.

Male genitalia: Uncus moderately long and broad, sickle shaped, curved, setosed with small setae, well sclerotized; acrotergite well developed; fenestrula absent; tegumen longer than uncus, u-shaped; vinculum shorter than tegumen, broad u-shaped; saccus well developed. Valvae with costa narrow, produced to a small plough like structure, sclerotized; sacculus strongly sclerotized with small rod like outgrowth towards distal end; harpe+ampulla simple plate like; cucullus sclerotized, dolphin's nose like; valvula not differentiated from cucullus, setosed with moderately long setae. Transtilla membranous; juxta well developed, sclerotized plate like; aedeagus moderately long and broad, carina penis double spined; vesica membranous with two patches of small sclerotized spines; ductus ejaculatorius entering subapically.

Wing expanse (Half): Male $20 \mathrm{~mm}$.

Material examined: 1 male, 02.x.2005, Malshej Ghat, Maharashtra, 690m; 2 males, 05.x.2005, Mahabaleshwar, Maharashtra, 1320m.

Remarks: The present species i.e., castanea Hampson was described under genus Diacrisia Hübner by Hampson in 1901. Critical examination of its external genitalic structures revealed that it does not conform to the characterization of type species of Diacrisia Hübner. Therefore, the new combination for this species has been proposed by transferring it under Spilarctia Butler. The male genitalia of this taxon has been described and illustrated in detail for the first time. The species has also been recorded for the first time from India.

\section{Spilarctia bifascia Hampson comb. rev.} (Figure 3)

Spilarctia bifascia Hampson, 1891: 8, male, type locality India (Nilgiri Hills); type depository NHM, London and examined by the junior author.

Spilosoma bifasciatum (Hampson) Hampson, 1894, Fauna Br. Ind. Moths, 2: 9.

Diacrisia obliqua (Walker) Hampson, 1901, Cat.Lep. Phal., 3: 289.

Male genitalia: Uncus strongly built, sickle shaped, setosed with fine setae, sclerotized, tip pointed; acrotergite well developed; fenestrula absent; tegumen longer than uncus, u-shaped; vinculum shorter than tegumen, v-shaped; saccus well developed. Valvae with costa narrow and weakly sclerotized; sacculus sclerotized, produced to an outgrowth towards distal end; harpe+ampulla simple plate like; cucullus rounded; valvula simple, setosed with long setae. Transtilla sclerotized bar like; juxta well developed, plate like; aedeagus long and moderately broad, almost straight; carina penis convex lens like with convex surface bearing small spines; vesica membranous with irroration of small spine, two patches of large spines present; ductus ejaculatorius entering subapically.

Wing expanse (Half): Male $22 \mathrm{~mm}$.

Material examined: 3 males, 25.xi.2003, Bhagamandala, Karnataka, 900m; 1 male, 12.ix.2004, Vallakadava, Kerala, 780m.

Remarks: The above said species bifascia Hampson was shifted under genus Diacrisia Hübner as a 'form' of Diacrisia obliqua Walker by Hampson in 1901. But the detail examination of genitalic structures like shape of uncus, juxta, valvae and aedegus of bifascia Hampson clearly conform that it is better to place this taxa under genus Spilarctia Butler. Therefore, the original status of this species has been revived in the present work and male genitalic structures are discussed and illustrated in detail for the first time.

\section{Spilarctia coorgensis sp. nov. (Figure 4)}

Head with frons and vertex ochreous. Antennae bipectinate in males; scape and pedicel ochreous; shaft and branches dark brown. Eyes fuscus green with black spots or patches. Labial palpi porrect; laiden with crimson scales; third segment brown.

Thorax, collar and tegula ochreous, thorax with a small black streak. Forewing with ground colour ochreous, slightly irrorated with crimson scales; costa suffused with crimson scales; a basal black spot; antemedial spot on vein $1 \mathrm{~A}$; a black speck at end of cell; an oblique series of postmedial spots on both sides of veins, not reaching costa; traces of submarginal series of black spots; underside with irroration of crimson scales; a black spot at end of cell; fringe ochreous; vein $R_{1}$ from cell; $R_{2}, R_{3}$, $\mathrm{R}_{4}$ and $\mathrm{R}_{5}$ from a common stalk; $\mathrm{M}_{1}$ from upper angle; $\mathrm{M}_{2}$ slightly beyond angle; $\mathrm{M}_{3}$ from angle of cell; $\mathrm{Cu}_{1}$ near angle of cell; $\mathrm{Cu}_{2}$ from middle of cell. Hindwing with ground colour ochreous; inner margin suffused with crimson scales; a black spot at end of cell; more or less complete series of submarginal spots; underside same; fringe ochreous; vein $\mathrm{Sc}+\mathrm{R}_{1}$ originating before middle of cell; $R$ s and $M_{1}$ from upper angle; $M_{2}$ towards middle of discocellulars; $\mathrm{M}_{3}$ and $\mathrm{Cu}_{1}$ from lower angle; $\mathrm{Cu}_{2}$ from middle of cell. Legs black brown; coxae and trochanter suffused with crimson scales; hind tibia with two pair of spurs.

Abdomen crimson; dorsal and lateral series of black spots; underside and tuft ochreous. Male genitalia with 

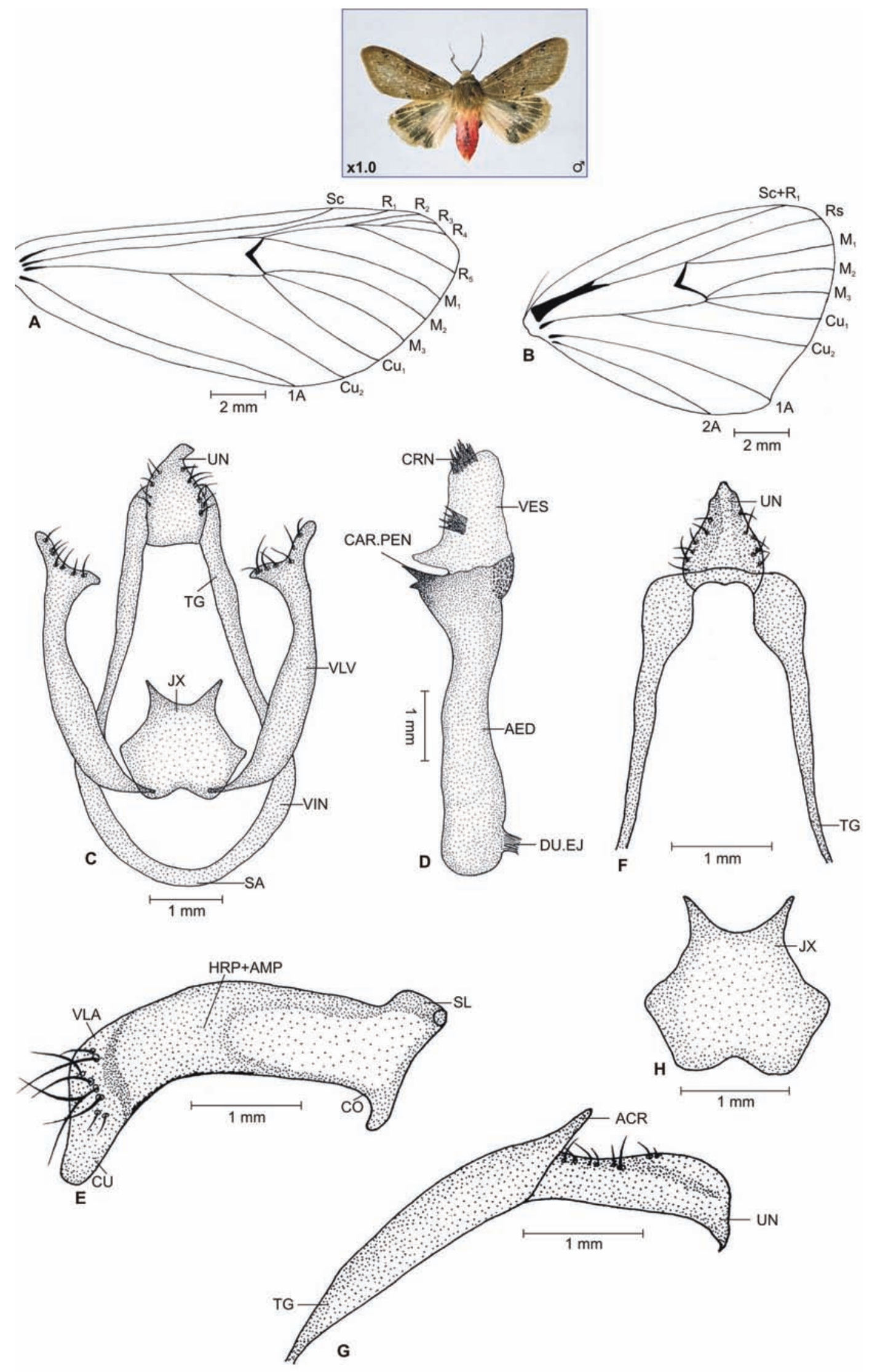

Figure 2. Spilarctia castanea (Hampson) comb. nov. A - Forewing, B - Hindwing, C - Male genitalia, D - Aedeagus, E - Valva (right), F - Uncus with Tegumen (dorsal view), G - Uncus with Tegumen (lateral view), H - Juxta (enlarged) 


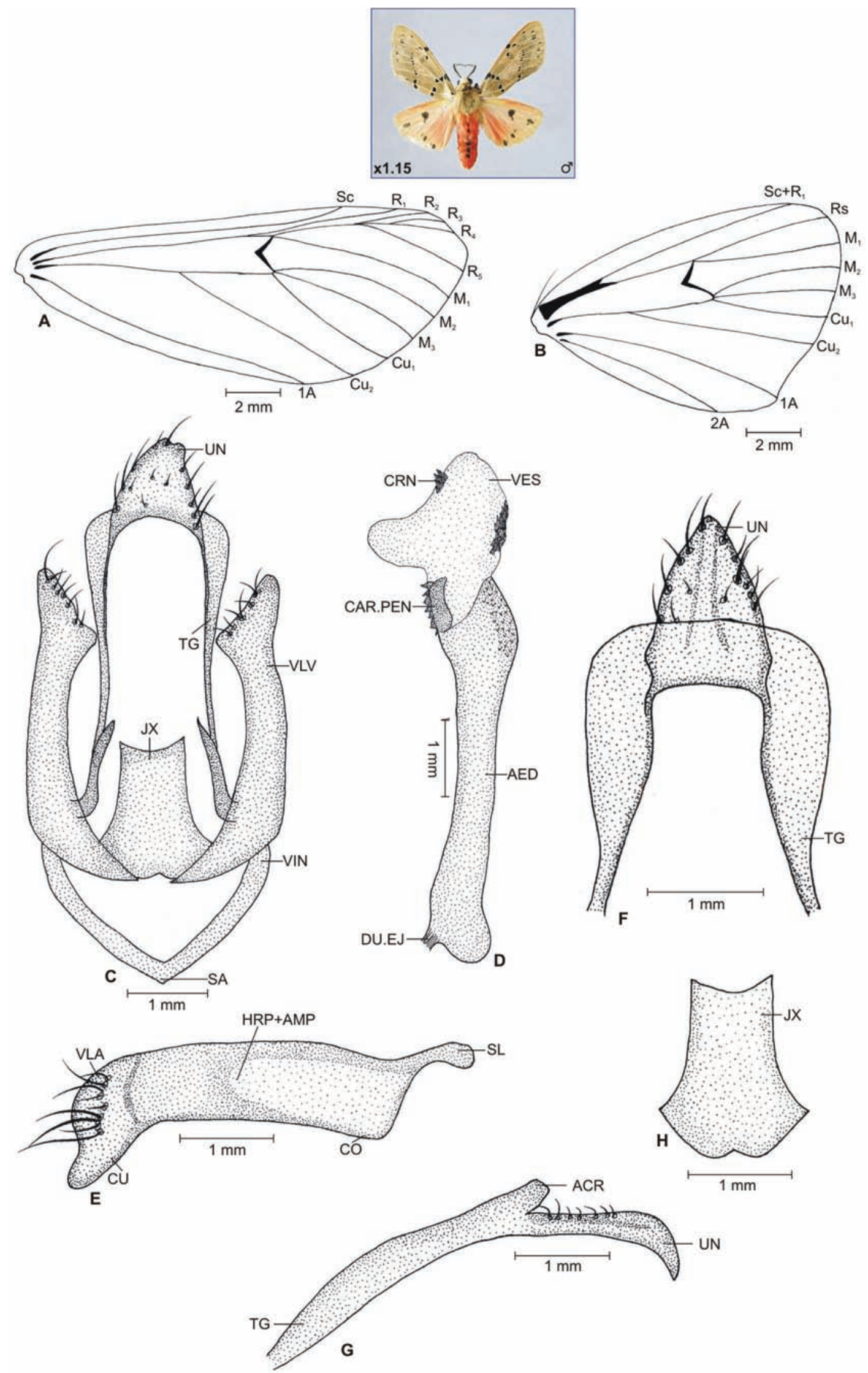

Figure 3. Spilarctia bifascia Hampson comb. rev. A - Forewing, B - Hindwing, C - Male genitalia, D - Aedeagus, E - Valva (right), F - Uncus with Tegumen (dorsal view), G - Uncus with Tegumen (lateral view), H - Juxta (enlarged) 


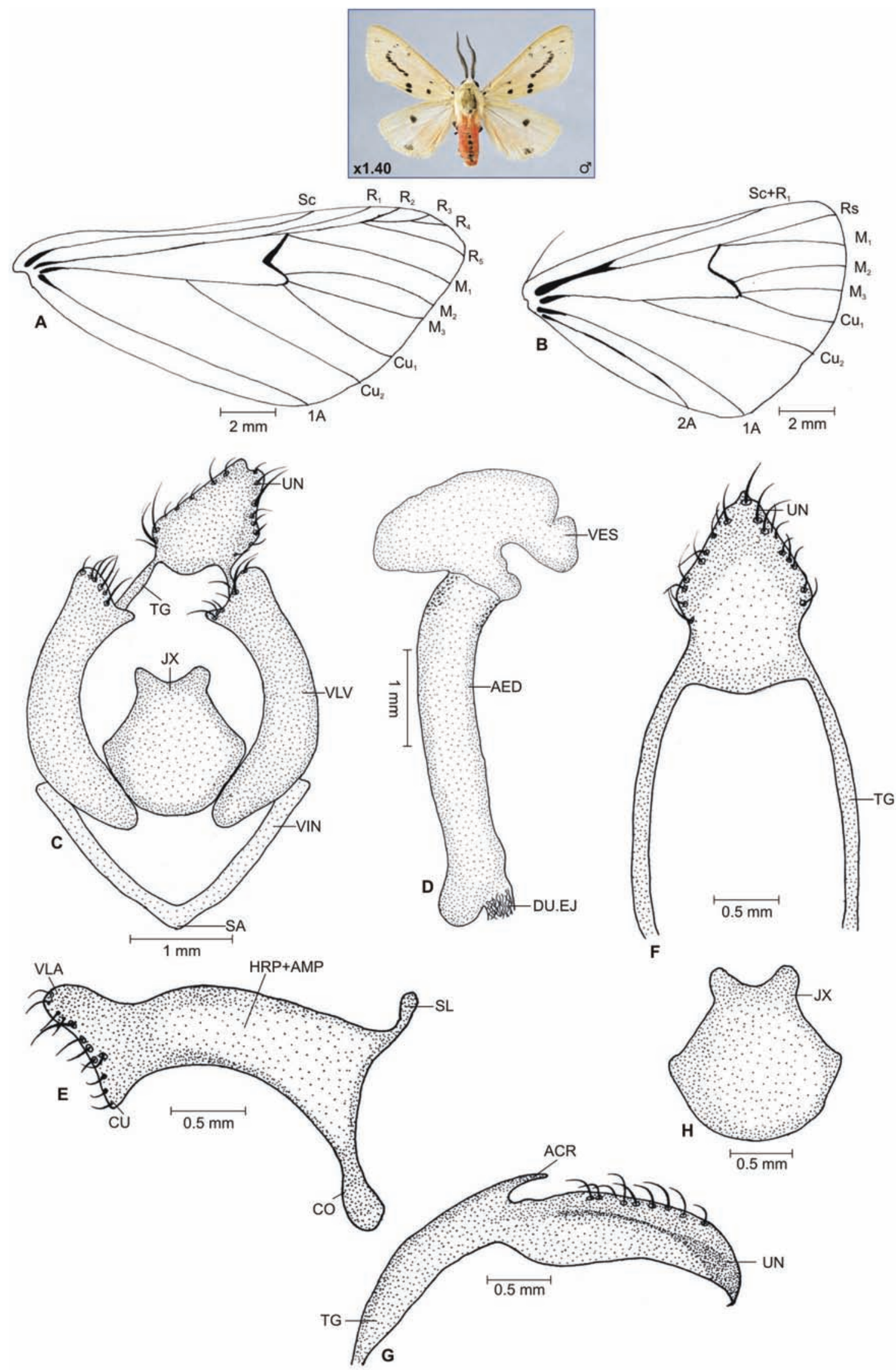

Figure 4. Spilarctia coorgensis sp. nov. A - Forewing, B - Hindwing, C - Male genitalia, D - Aedeagus, E - Valva (right), F - Uncus with Tegumen (dorsal view), G - Uncus with Tegumen (lateral view), H - Juxta (enlarged) 
uncus strongly built, curved towards distal end, setosed with small setae, well sclerotized, tip pointed; acrotergite present; fenestrula absent; tegumen as long as uncus, broad u-shaped; vinculum longer than tegumen, v-shaped, well sclerotized; saccus developed. Valvae simple with costa produced to an outgrowth towards proximal end; sacculus differentiated; harpe + ampulla simple plate like; cucullus and valvula not distinct; tip of valvae setosed with short setae. Transtilla sclerotized; juxta well developed; aedeagus long and broad, curved; carina penis absent; vesica membranous with irroration of small spines; ductus ejaculatorius entering subapically.

Wing expanse (Half): Male $15 \mathrm{~mm}$.

Material examined:

Holotype: Male, 30.vii.2004, Bhagamandala, Coorg, Karnataka, $1^{\circ} \mathrm{N} \& 75^{\circ} \mathrm{E}, 900 \mathrm{~m}$, coll. N.S. Gill, PUPZOO/MUS-078.

Paratype: 2 males, 15.ix.2004, Vithura, Kerala, $10^{\circ} 00^{\prime} \mathrm{N} \& 7^{\circ} 25^{\prime} \mathrm{E}, 120 \mathrm{~m}$, coll. N.S. Gill, PUPZOO/MUS078a, PUPZOO/MUS-078b, Zoology Museum, Dept. of Zoology, Punjabi University.

Remarks: Morphologically the species under reference is closely allied to obliqua Walker. But the perusal of external male genitalic structures reveals that it is a different species. Its distinct male genitalic characters like shape of vinculum, juxta and valvae justify its status.

Etymology: The name of the species belong to the district of its type locality i.e., Coorg (Kodagu).

\section{Spilarctia obliqua (Walker) (Figure 5)}

Spilosoma obliqua Walker, 1855: 3, female, type locality Japan, type depository NHM, London and examined by the junior author.

Diacrisia obliqua (Walker) Hampson, 1901, Cat. Lep. Phal., 3: 289.

Spilarctia obliqua (Walker) Koda, 1988, Tyo to Ga, 39(1): 67.

Material examined: 2 males, 27.ix.2005, Waghai, Gujarat, 180m; 1 male, 28.vii.04, Madikeri, Karnataka, 1100m; 1 male, 19.vii.2004, Ganeshgudi, Karnataka, 480m; 1 male, 28.ix.2003, Gudalur, Tamil Nadu, 900m; 3 males, 6.ix.2004, Rani, Kerala, 40m; 6 males, 4.ix.2004, Vithura, Kerala, 120m; 1 male, 7.ix.2004, Vadasserikkara, Kerala, 30m.

Remarks: The species has been discussed in considerable detail by many previous authors like Koda (1988) and Kirti \& Singh (1994). Hence, the description is being omitted in the present study, whereas the illustrations are given for the sake of comparison.

\section{Spilarctia casigneta (Kollar) (Figure 6)}

Euprepia casigneta Kollar, 1844: 4, male, type locality India, type depository NHM, London and examined by the junior author.

Spilarctia sagittifera Moore, 1888, Proc. Zool. Soc., 1888: 394.

Spilosoma casignetum (Kollar) Hampson, 1894, Fauna Br. Ind. Moths, 2: 9.

Diacrisia casigneta (Kollar) Hampson, 1901, Cat. Lep. Phal., 3 : 291.

Spilarctia casigneta (Kollar) Koda, 1988, Tyo to Ga, 39(1): 66.

Male genitalia: Uncus strongly built, beak shaped, sclerotized, setosed with fine setae, tip pointed and slightly curved; acrotergite present; fenestrula absent; tegumen longer than uncus, broad u-shaped, corrugated at junction of uncus and tegumen; vinculum shorter than tegumen, v-shaped, well sclerotized; saccus developed. Valvae with costa linear, weakly sclerotized; sacculus well sclerotized; harpe+ampulla double ridged with suffusion of long setae; cucullus rounded; valvula simple. Transtilla membranous; juxta well developed; aedeagus long and moderately broad, curved; carina penis represented by a strong sclerotized spine; vesica membranous with a well formed patch of spines; ductus ejaculatorius entering subapically.

Wing expanse (Half): Male 24-26 mm.

Material examined: 2 males, 19.iv.2003, Kodai Kanal, Tamil Nadu, 2133m; 1 male, 2.x.2003, Coonoor, Tamil Nadu, 1880m; 1 male, 13.ix.2004, Devikulum, Kerala, $1620 \mathrm{~m}$.

\section{Spilarctia todara (Moore) comb. rev. (Figure 7)}

Spilosoma todara Moore, 1872, Sex : Female, Type locality : India, Type depository NHM, London and examined by the Junior Author.

Spilarctia todara (Moore) Cotes \& Swinhoe, 1887, Cat. Moths India, 2: 42.

Spilosoma todarum Moore; Hampson, 1894, Fauna Br. Ind. Moths, 2: 7.

Diacrisia obliqua (Walker) Hampson, 1901, Lep. Cat. Phal., 3: 289.

Male genitalia: Uncus strongly built, sharply narrow towards tip, well sclerotized, setosed with short setae, tip pointed; acrotergite well developed; fenestrula absent; tegumen longer than uncus, broad u-shaped; vinculum shorter than tegumen, v-shaped, sclerotized; saccus developed. Valvae with costa narrow, linear, weakly sclerotized; sacculus sclerotized, produced to an outgrowth towards distal end; harpe+ampulla single ridged structure; cucullus rounded; valvula simple. Transtilla membranous; 

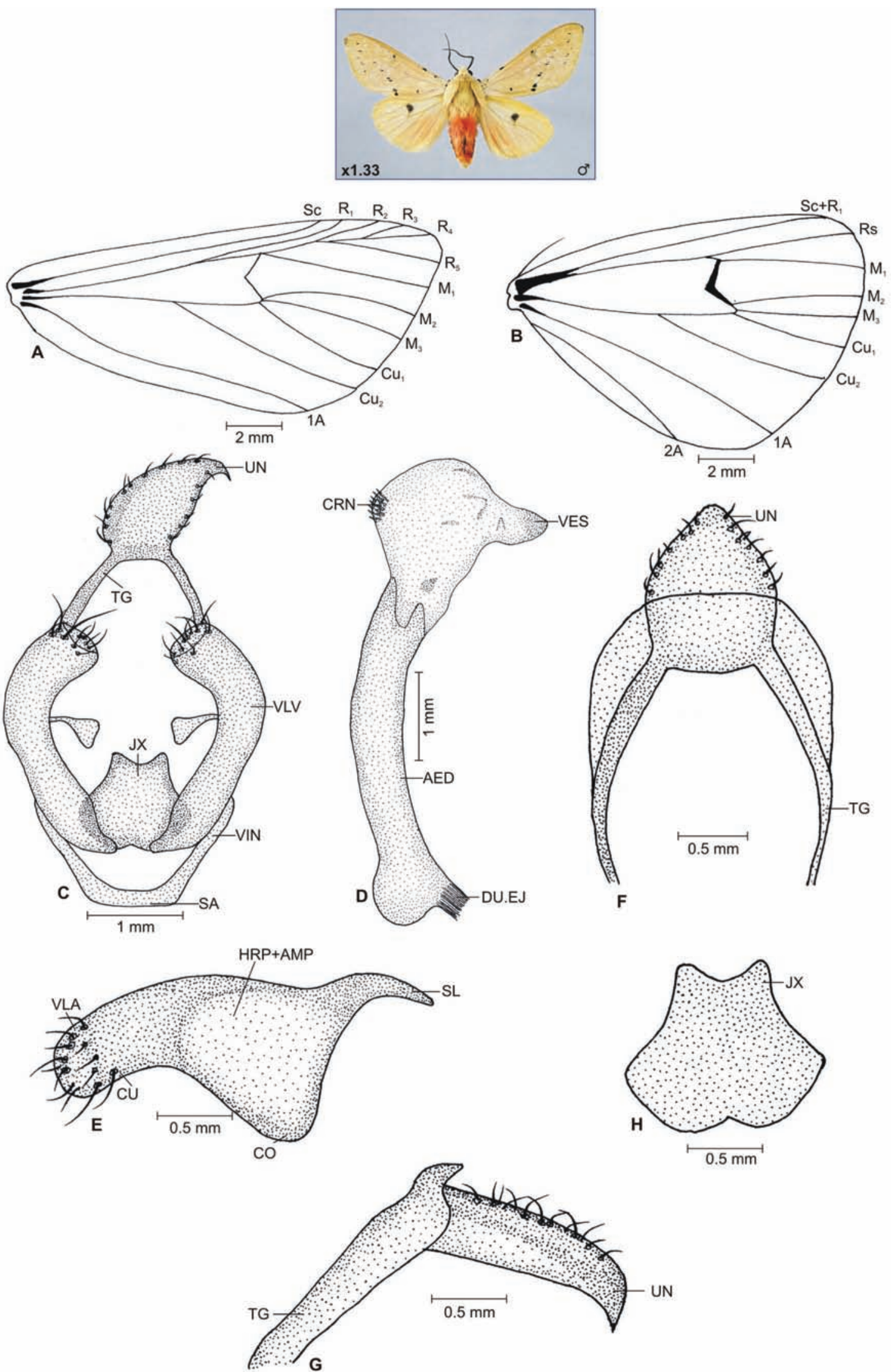

Figure 5. Spilarctia obliqua (Walker). A - Forewing, B - Hindwing, C - Male genitalia, D - Aedeagus, E - Valva (right), F - Uncus with Tegumen (dorsal view), G - Uncus with Tegumen (lateral view), H - Juxta (enlarged) 


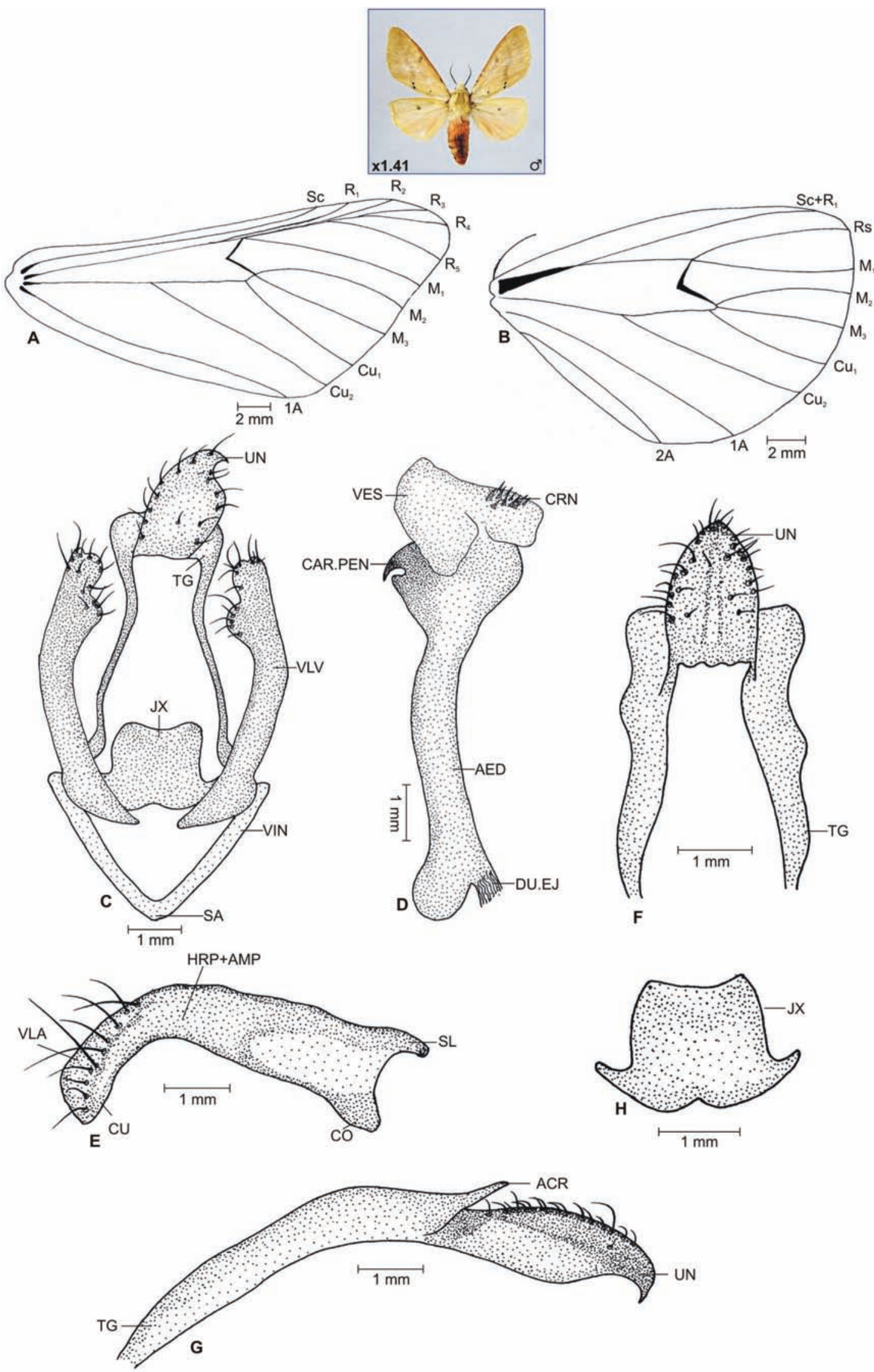

Figure 6. Spilarctia casigneta (Kollar). A - Forewing, B - Hindwing, C - Male genitalia, D - Aedeagus, E - Valva (right), F - Uncus with Tegumen (dorsal view), G - Uncus with Tegumen (lateral view), H - Juxta (enlarged) 

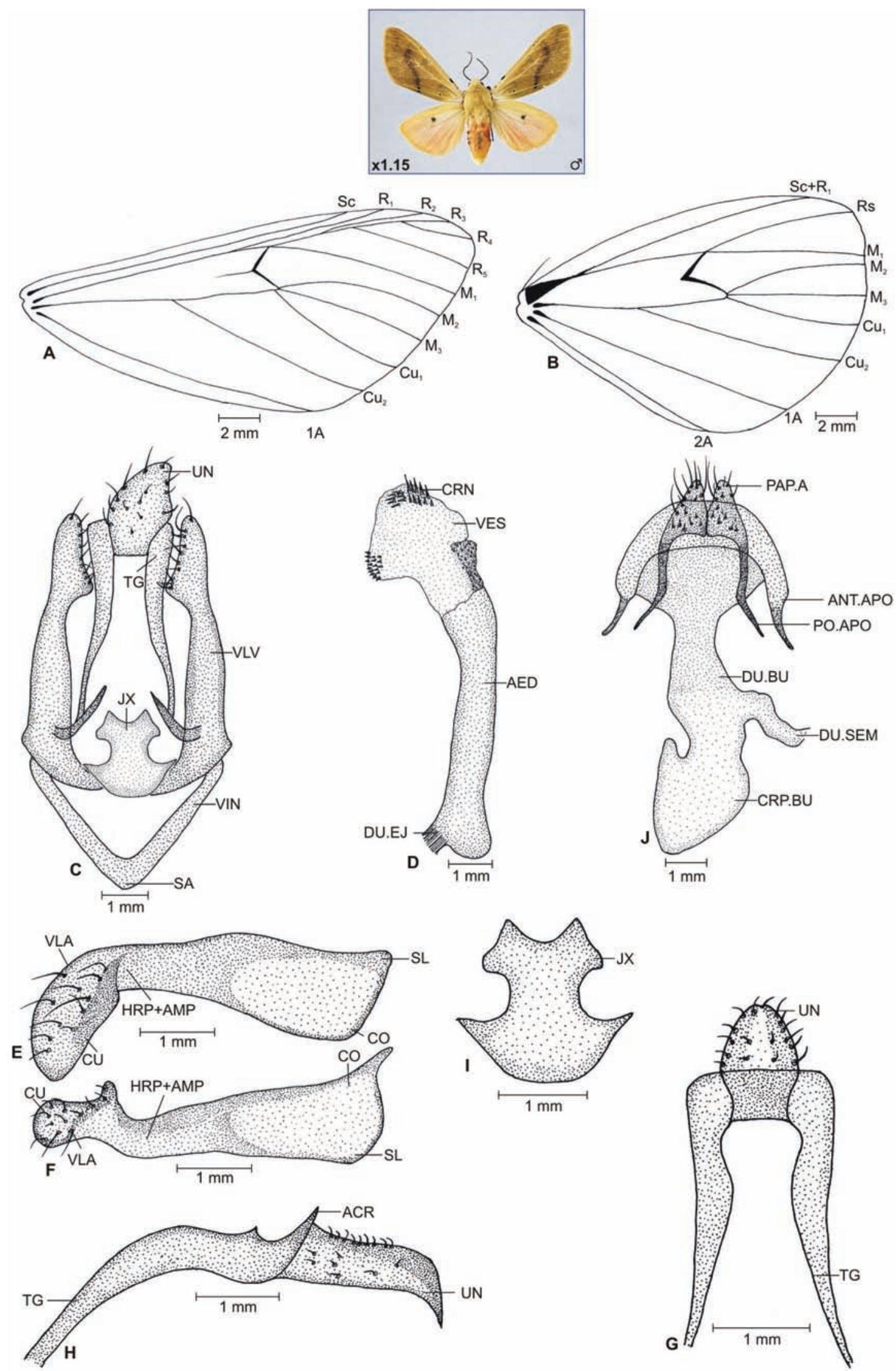

Figure 7. Spilarctia todara (Moore) comb. rev. A - Forewing, B - Hindwing, C- Male genitalia, D - Aedeagus, E - Valva (right), F - Valva (right, different view), G - Uncus with Tegumen (dorsal view), H - Uncus with Tegumen (lateral view), I - Juxta (enlarged), J - Female genitalia 
A key to all the studied species have been formulated and given below:

1. Abdomen covered with orange yellow scales

mona (Swinhoe) comb. nov.

Abdomen covered with crimson scales

2

2. Frons, vertex, thorax, tegula, collar and forewing with general ground colour dark brown to pale brown;

male genitalia with vesica bearing two patches of spines

Frons, vertex, thorax, tegula, collar and forewing with general ground colour white to ochreous; male genitalia with vesica bearing more or less than two patches of spines...... Hindwing with ground colour fuscus; abdomen with dorsal series of black spots; male genitalia with vinculum broad u-shaped; carina penis double spined. castanea (Hampson) comb. nov. Hindwing with ground colour ochreous, costal and inner margin crimson; abdomen with dorsal, lateral and sublateral series of black spots; male genitalia with vinculum v-shaped; carina penis convex lens like bifascia Hampson comb. rev. Male genitalia with tegumen as long as uncus; vesica irrorated with small spines, a well formed patch of spines absent.

- $\quad$ Male genitalia with tegumen longer than uncus; vesica with well formed patch or patches of spines............6

5. Abdomen with dorsal and lateral series of black spots; male genitalia with vinculum longer than tegumen, v-shaped; costa produced to an outgrowth towards proximal end. coorgensis sp. nov. Abdomen with dorsal, lateral and sublateral series of black spots; male genitalia with vinculum shorter than tegumen, u-shaped; costa simple and linear. obliqua (Walker)

6. Abdomen with black spots obsolete; male genitalia with aedeagus curved, carina penis in form of single large spine; vesica with single patch of spines. casigneta (Kollar) Abdomen with dorsal and lateral series of black spots; male genitalia with aedeagus almost straight, carina penis absent; vesica with three patches of spines. todara (Moore) comb. rev.

juxta well formed, dumble shaped; aedeagus long and moderately broad, almost straight; carina penis absent; vesica membranous with a sclerotization at base, cornuti in form of three patches of sclerotized spines; ductus ejaculatorius entering subapically.

Female genitalia: Corpus bursae triangular, membranous, signum absent; ductus bursae moderately long and broad, sclerotized; ductus seminalis entering at junction of ductus seminalis entering ductus bursae and corpus bursae; anterior apophyses shorter than posterior apophyses; papilla analis setosed with long and short setae.

Wing expanse (Half): Male $23 \mathrm{~mm}$; female $24 \mathrm{~mm}$.

Material examined: 1 male, 26.xi.2005, Kodanadu, Tamil Nadu, 1920m; 3 males, 1.x.2003, Coonoor, Tamil Nadu, 1880m; 1 male, 2.x.2003, Kotagiri, Tamil Nadu, 2020m; 1 male, 22.xi.2005, Kotagiri, Tamil Nadu, 2020m; 1 male, 13.ix.2004, Devikulum, Kerala, 1620m; 1 male, 14.ix.2004, Devikulum, Kerala, 1620m.

Remarks: The species under reference was shifted as a 'form' of obliqua Walker under genus Diacrisia Hübner by Hampson in 1901 . The present work deals with the detail study of its male and female genitalic structures which confirms its status as a distinct species. Hence, the original combination of todara Moore with genus Spilarctia Butler has been revived.

\section{REFERENCES}

Arora, G.S. (1983). On the Lepidopterous fauna of Andaman and
Nicobar group of Islands (India). Family Arctiidae. Record of Zoological Survey of India, Occasional Papers 60: 1-49.

Arora, G.S. \& M. Chaudhary (1982). On the Lepidopterous fauna of Arunachal Pradesh and adjoining areas of Assam in North-East India. Family Arctiidae. Zoological. Survey of India, Technical Monograph 6: 1-63.

Butler, A.G. (1875). Revision of the genus Spilosoma and the allied groups of the family Arctiidae. Cistula Entomologica 2: 21-39.

Cotes, E.C. \& C. Swinhoe (1887-89). Catalogue of the moths of India. Sphinges and bombyces 2: 42.

Common, I.F.B. (1970). Lepidoptera (Moths and Butterflies), in the Insect of Australia. Melbourne Universtiy Press, Melbourne, 866pp.

Daniel, F. (1943). Beitrage Zur Kenntnis der Arctiidae Ostasiens under besonderer Beriicksichtingung der Ausbeuten. $\mathrm{H}$. Hones aus diesens Gebiets Lep. Het., Part 1, Callimorphinae and Nyctemerinae. Mitteilungen der Schweizerische Entomologische Gesellschaft 33: 247-269.

Hampson, G.F. (1891). Illustrations of typical specimens of Lepidoptera Heterocera in the collections of British Museum - Heterocera of Nilgiri district, 8, Tylor and Francis Ltd., London, 46-55pp.

Hampson, G.F. (1893). Illustrations of typical specimens of Lepidoptera Heterocera in the collections of British Museum - The Macrolepidoptera Heterocera of Ceylon, 9, Tylor and Francis Ltd., London, 79pp.

Hampson, G.F. (1894). Fauna of British India, Moths, including Ceylon and Burma - 2. Taylor and Francis Ltd., London, 609pp.

Hampson, G.F. (1901). Catalogue of the Arctiidae and Agaristidae in the collection of the British Museum - 3. Taylor and Francis Ltd., London, 690pp.

Holloway, J.D. (1988). Moths of Borneo Part - 6. Kaulalampur Southden, Malaysia, $101 \mathrm{pp}$.

Hübner (1819). Verzeichnis aller bisher bey den Fürbildungen zur Sammlung europäischer Schmetterlinge 11: 169.

Hufnagel (1766). Tabelle uber heiesigen nachtvogel. v. Dritte 
tabelle von dene inscted order die erste von den Nachtvge. Berlin Magazin 2(4): 412.

Kaleka, A.S. (2005). A new combination under genus Thanatarctia for a moth species (Lepidoptera : Arctiidae). Bionotes 7(3): 93-94.

Kirti, J.S. \& A. Singh (1994). Genitalic studies on four Indian species of genus Spilarctia Butler (Arctiidae: Lepidoptera). Uttar Pradesh Journal of Zoology 14(1): 87-88.

Koda, N. (1988). A generic classification of the subfamily Arctinae of Palearctic and Oriental regions based on male and female genitalia (Lepidoptera: Arctiidae) Part-II. Tyo to ga 38(3): 1-79.

Kollar, V. (1844). Lepidoptera in C.F. Von. thegel, "Kaschmir und das Reich der sick," Stuttgart 4(2) : 403-495.

Moore, F. (1872). Descriptions of new Indian Lepidotera. Proceedings Zoological Society $1872: 555-583$.

Moore, F. (1888). Proceedings Zoological Society 1888: 394

Robinson, G.S. (1976). The preparation of slides of Lepidoptera genitalia with special reference to Microlepidoptera. Entomologist's Gazette 27: 127-132.

Seitz, A. (1910). Palearctic Bombyces and Sphinges. Family Arctiidae. The Macrolepidoptera of the World 2 : 43-109.

Stephens (1828). Illustrations of British Entomology or a synopsis of indigenous insects. Illustrations British Entomology Haustellata 2(1): 1-90.

Strand, E. (1919). Arctiidae: Arctiinae. Lepidopterorum Catalogus 22: 1-416.

Swinhoe, C. (1885). Proceedings of Zoological Society 1885: 20.

Walker, F. (1855). List of the specimens of Lepidopterous insects in the collection of the British Museum. Catalogue Lepidoptera Heterocera 3: 583-762.

Zimmerman, E.C. (1978). Microlepidoptera Insects of Hawaii - 9. University Press of Hawaii, Honolulu, 1903pp.
Author Details: JAGBIR SINGH KIRTI is working as a professor in the Department of Zoology, Punjabi University, Patiala. He is an eminent lepidopterist. He has been working on the taxonomy of Family Arctiidae since 1994. So far he has published 120 research papers, and completed five major research projects and working on three more projects. Presently, he is working on the second major DST research project on the taxonomic revision of Indian Arctiidae (Part-ii).

NAVNEET SINGH GILL is working as a lecturer in entomology in the Department of Agriculture, Baba Farid College, Bathinda. He has published 17 research papers and is presently, working as an organizing secretary of a National Conference on Agriculture to be held on September 2-3, 2010.

Author Contribution: The First author is the supervisor of the second author and has guided the second author in all research pursuits. He has interpreted the data collected by the junior author and brought it to conclusion. The second author has made the collections and studied the collected material in respect of their genitalic and external morphological features besides writing other details of different species. 